\title{
PENGEMBANGAN MODEL PEMBELAJARAN MENULIS KARYA ILMIAH BERPENDEKATAN KONSTRUKTIVISME
}

\author{
Supriyadi \\ Fakultas Sastra dan Budaya Universitas Negeri Gorontalo \\ email: supriyadiung@yahoo.co.id
}

\begin{abstract}
Abstrak
Penelitian pengembangan ini bertujuan menghasilkan model pembelajaran keterampilan menulis karya ilmiah dengan pendekatan konstruktivisme. Penelitian menggunakan model recursive reflective design and development (R2D2) dan researchdevelopment research (RDR). Model pembelajaran yang dikembangkan mencakup komponen: pengantar, konsep, keunggulan, tujuan, karakteristik, dan tahapan pembelajaran keterampilan menulis karya ilmiah dengan pendekatan konstruktivisme. Hasil uji ahli, uji pengguna/praktisi, dan uji lapangan menunjukkan bahwa model pembelajaran yang dikembangkan terbukti dapat meningkatkan kemampuan mahasiswa menulis karya ilmiah, baik pada proses maupun hasil. Indikator keberhasilan proses tampak pada keaktifan dan ketekunan mahasiswa dalam melaksanakan tahapan-tahapan kegiatan menulis karya ilmiah dengan pendekatan konstruktivisme. Indikator keberhasilan hasil tampak pada peningkatan kualitas karya tulis ilmiah mahasiswa, baik pada aspek isi/ substansi maupun aspek mekanik (ejaan dan tata tulis).
\end{abstract}

Kata kunci: model pembelajaran, menulis karya ilmiah, pendekatan konstruktivisme

\section{DEVELOPING AN ACADEMIC WRITING LEARNING MODEL USING THE CONSTRUCTIVIST APPROACH}

\begin{abstract}
This research and development study aims to produce a model of the learning of academic writing skills using the constructivist approach. The study employed the recursive reflective design and development (R2D2) and research-development research (RDR) models.The developed learning model includes the components of: introduction, concepts, advantages, objectives, characteristics, and steps in the learning of academic writing skills using the constructivist approach. The results of expert, user/practitioner, and field testing showed that the developed learning model could improve the students' academic writing skills in terms of the process and the product. The success in the process was indicated by their activeness and seriousness in the steps of academic writing activities using the constructivist approach. The success in the product was indicated by the improvement of their academic writing quality in the aspects of contents/substances and mechanics (spelling and punctuation).
\end{abstract}

Keywords: learning model, academic writing, constructivist approach

\section{PENDAHULUAN}

Pembelajaran keterampilan menulis karya ilmiah (disingkat MKI) di perguruan tinggi harus dikelola dengan baik agar mampu mendorong mahasiswa mandiri dalam bernalar, mampu melihat keterkaitan antarkonsep dan materi, mampu berkomunikasi tulis, mampu 
menemukan sendiri pengetahuan dan keterampilan, dan mampu memecahkan masalah yang sedang dihadapi dalam hal menulis karya ilmiah. Selaras dengan itu, mahasiswa harus dilatih berinteraksi dan bernegosiasi dengan baik dengan lingkungan sekitarnya, diberi kesempatan melakukan refleksi atas proses belajar yang dijalani, dan diberi kesempatan mengembangkan strategi belajarnya sendiri. Dengan demikian, mahasiswa dapat mengembangkan kemampuan dan keterampilan yang dimiliki dengan sebaik-baiknya.

Konsep pembelajaran tersebut adalah konsep pembelajaran berpendekatan konstruktivisme (Vygotsky, 2002). Keterlibatan mahasiswa secara fisik dan kejiwaan dalam proses pembelajaran harus lebih diutamakan. Mahasiswa didorong menemukan dan mengonstruksi sendiri pengetahuan dan keterampilan yang sedang dipelajari melalui penafsiran/ pemaknaan dan interaksi yang dilakukan dengan berbagai cara, seperti observasi, diskusi, tanya jawab, penemuan, berkolaborasi, atau pun percobaan (Vygotsky, 1978). Dosen sebaiknya juga memberikan kesempatan kepada mahasiswa bertanggung jawab dalam menyelesaikan tugastugas belajarnya secara mandiri.

Pembelajaran berpendekatan konstruktivisme menunjukkan sejumlah keunggulan dibandingkan dengan pembelajaran berpendekatan konvensional. Pembelajaran berpendekatan konstruktivisme menjanjikan paritisipasi aktif mahasiswa dan mahasiswa dipandang sebagai fokus pembelajaran (Shymansky, 1992). Pembelajaran berpendekatan konstruktivisme juga dianggap dapat mewujudkan suatu pembelajaran yang demokratis (Basuki, 2008). Sebagai sebuah model pembelajaran yang demokratis di dalamnya mahasiswa dapat bekerja sama, berdiskusi, saling bertukar pikiran, saling memberi dan menerima pendapat teman, saling mengoreksi pekerjaan teman, dan saling membantu dalam belajarnya.
Proses pembelajaran berpendekatan konstruktivisme bersifat kooperatif (Suparno, 1997). Proses pembelajaran yang sifatnya kooperatif itu muncul ketika mahasiswa bekerja bersama-sama untuk mencapai tujuan belajar yang diinginkan oleh semua mahasiswa. Pengelolaan kelas dalam pembelajaran kooperatif bertujuan membantu mahasiswa mengembangkan niat dan kiat bekerja sama dan berinteraksi dengan mahasiswa lain. Ada tiga hal penting yang perlu diperhatikan dalam pengelolaan kelas dalam pembelajaran kooperatif, yaitu pengelompokan, semangat kooperatif, dan penataan kelas.

Dengan mengacu pada prinsip pembelajaran berpendekatan konstruktivisme yang menjanjikan suatu proses pembelajaran yang inovatif-kreatif-konstruktifkooperatif, dipandang penting proses pembelajaran keterampilan menulis karya ilmiah mengadopsi pendekatan konstruktivisme. Hal itu di dasarkan atas pertimbangan bahwa berdasarkan hasil observasi proses pembelajaran menulis karya ilmiah selama ini cenderung berpendekatan konvensional dan dosen dipandang sebagai orang yang "mahatahu" dan fokus pembelajaran berada pada dosen. Proses pembelajaran berpendekatan konvensional tidak memberikan kebebasan dan keleluasaan mahasiswa untuk mandiri dalam membangun pengetahuan dan keterampilannya. Dosen masih memegang peranan yang dominan dalam membangun pengetahuan dan keterampilan mahasiswa. Pengetahuan berasal dari dosen karena dosen terbiasa menjelaskan konsep-konsep ilmiahnya kepada mahasiswa kemudian diikuti dengan sejumlah tugas yang harus dikerjakan oleh mahasiswa. Pekerjaan mahasiswa harus diselesaikan sesuai dengan konsep keilmuan yang dijelaskan oleh dosen.

Penerapan pendekatan konstruktivisme yang bersifat kooperatif dalam pembelajaran menulis karya ilmiah dipandang tepat karena substansi materi pem- 
belajaran menulis karya ilmiah menuntut kemandirian mahasiswa dalam mengusai pengetahuan dan keterampilan ilmiahnya. Materi pembelajaran keterampilan menulis karya ilmiah tidak dapat semata-mata dijelaskan secara teoretis dan verbalistis oleh dosen, melainkan harus dikonstruksi sendiri oleh mahasiswa dengan bekerja sama dengan teman sejawatnya dibawah bimbingan dosen. Materi pembelajaran keterampilan menulis karya ilmiah menuntut pemikiran yang tinggi dan problematik dari mahasiswa. Oleh sebab itu, pembelajaran keterampilan menulis karya ilmiah harus dialami dan dikonstruksi sendiri oleh mahasiswa melalui interaksi dengan lingkungan sossialnya (Vigotsky, 1978). Lingkungan sosial mahasiswa berupa teman sejawat, dosen, ahli, dan masyarakat sekitarnya)

Pendekatan konstruktivisme dalam pembelajaran memandang mahasiswa sebagai subjek pembelajaran dan bukan objek pembelajaran. Mahasiswa sebagai subjek pembelajaran akan berupaya menemukan sendiri cara memilih tema, mengidentifikasi dan memilih topik, merumuskan topik menjadi judul tulisan, merumuskan masalah, menyusun kerangka tulisan, menyusun tesis, mengembangkan gagasan dan gugus paragraf untuk membahas masalah yang diajukan, sampai pada penarikan simpulan. Proses konstruksi pengetahuan dan keterampilan ilmiah tersebut tidak semata-mata dilakukan sendiri oleh mahasiswa, akan tetapi melalui proses interaksi dengan lingkungan sosial dan tetap dalam bimbingan dosen. Mahasiswa tidak dapat dilepaskan sendiri tanpa bimbingan dosen dalam memperoleh pengetahuan dan keterampilan ilmiahnya

Sehubungan dengan itu, pengembangan model pembelajaran keterampilan menulis karya ilmiah berpendekatan konstruktivisme ini dilakukan dalam rangka membantu dosen dalam memandu jalannya proses pembelajaran. Dosen perlu rambu-rambu khusus dalam melaksanakan proses pembelajaran menulis karya ilmiah berpendekatan konstruktivisme. Diharapkan dengan tersedianya model pembelajaran berpendekatan konstruktivisme produk pengembangan ini dosen dapat melaksanakan proses pembelajaran keterampilan menulis karya ilmiah sesuai dengan prinsip-prinsip pembelajaran berpendekatan konstruktivisme. Di sisi lain, model pembelajaran yang dikembangkan ini juga dapat dimanfaatkan untuk memotivasi belajar mahasiswa, meningkatkan minat belajar, dan melakukan inovasi pembelajaran (Basuki, 2008). Dengan demikian, kualitas proses dan hasil pembelajaran keterampilan menulis karya ilmiah mahasiswa akan meningkat.

Pendekatan konstruktivisme yang dikenal sebagai pembelajaran generatif diyakini mampu mewujudkan proses pembelajaran keterampilan menulis karya ilmiah yang inovatif-kreatif-konstruktifkooperatif dan memperlakukan mahasiswa sebagai fokus belajar. Kegiatan orientasi konsep, eksplorasi konsep, interpretasi/penemuan konsep, aplikasi konsep, dan evaluasi adalah rangkaian proses pembelajaran berpendekatan konstruktivis yang jelas-jelas berfokus pada mahasiswa (Nurjanah, 2005). Dalam proses konstruksi pengetahuan dan keterampilan ilmiah yang dikuasainya mahasiswa harus menjalani langkah orientasi konsep, eksplorasi konsep, interpretasi/ penemuan konsep, aplikasi konsep, dan evaluasi. Penguasaan/konstruksi pengetahuan dan keterampilan ilmiah yang dialami sendiri oleh mahasiswa akan menancap kuat dalam benak pikiran mahasiswa. Hal itu akan berbeda bila pengetahuan dan keterampilan ilmiah disuapi oleh dosen melalui penjelasan yang besifat verbalistik. Penjelasan yang besifat verbalistik tidak akan dapat bertahan lama dalam benak pikiran mahasiswa. Itulah sejumlah penjelasan mengapa pendekatan konstruktivisme digunakan untuk mem-

Pengembangan Model Pembelajaran Menulis Karya Ilmiah Berpendekatan Konstruktivisme 
berikan ruh dalam pengembangan model pembelajaran keterampilan menulis karya ilmiah.

Model pembelajaran keterampilan menulis karya ilmiah yang dikembangkan memiliki ciri khas yang berbeda dengan model pembelajaran konvensional. Kekahasan tersebut tampak pada langkahlangkah pembelajaran dalam pendekatan konstruktivisme, yakni orientasi konsep, eksplorasi konsep, interpretasi/penemuan konsep, aplikasi konsep, dan evaluasi (Nurjanah, 2005. Sejumlah langkah pembelajaran itu memberikan warna tersendiri dalam proses pembelajaran yang mencerminkan pembelajaran menulis karya ilmiah yang inovatif-kreatif-konstruktifkooperatif dan memperlakukan mahasiswa sebagai fokus belajar.

Dalam konteks yang spesifik realisasi pengembangan model pembelajaran keterampilan menulis karya ilmiah berpendekatan konstruktivisme dipandang penting dan sangat dibutuhkan oleh dosen dan mahasiswa dalam proses pembelajaran. Alasannya, model pembelajaran keterampilan menulis karya ilmiah berpendekatan konstruktivismemerupakan panduan yang realistis dan mantap yang dapat dimanfaatkan dosen dan mahasiswa untuk mewujudkan proses pembelajaran yang inovatif-kreatif-konstruktif-kooperatif dan menempatkan mahasiswa sebagai subjek belajar dalam mengonstruksi pengetahuan dan keterampilan ilmiah yang dipelajarinya. Dikatakan mantap karena model pembelajaran produk pengembangan ini telah melalui serangkaian uji, yakni (a) uji ahli yang terdiri atas ahli materi pembelajaran menulis karya ilmiah, ahli metode pembelajaran menulis karya ilmiah, ahli teknologi pembelajaran, (b) uji praktisi, dan (c) uji lapangan pada kelompok kecil dan kelompok besar.

\section{METODE}

A Recursive, Reflective, Design, and Development Model (Willis, 1995; 2000) dan Research Development Research (Borg and Gall, 1983) yang lebih dikenal dengan singkatan R2D2 dan RDRdigunakan sebagai model pengembangan pembelajaran. Model R2D2 terdiri atas tiga fokus, yakni fokus (a) penetapan, (b) desain dan pengembangan, dan (c) diseminasi atau penyebarluasan. Fokus diseminasi/ penyebarluasan tidak dilakukan karena berkaitan dengan penerbitan produk dan implementasi produk di lapangan dalam skala luas. Model R2D2 digunakan sebagai model pengembangan karena sejalan dengan paradigma konstruktivisme yang menjiwai bahan ajar yang dikembangkan Sementara itu, model RDR terdiri atas tiga kegiatan, yakni (a) studi pendahuluan, (b) pengembangan, dan (c) uji efektivitas.

Fokus penetapan dilakukan dengan menetapkan produk pengembangan dan pembentukan tim partisipatif. Produk pengembangan adalah model pembelajaran menulis karya ilmiah berpendekatan konstruktivisme. Tim partisipatif yang berhasil dibentuk terdiri atas: (a) mahasiswa, (b) dosen, (c) praktisi, dan (d) ahli. Tim ahli terdiri atas (a) ahli materi menulis karya ilmiah (AMat), (b) ahli metode pembelajaran menulis karya ilmiah (AMet), dan (c) ahli teknologi pembelajaran (ATp).

Fokus desain dan pengembangan dalam R2D2 yang sejalan dengan D dalam RDR dilakukan dengan mendesain model pembelajaran dan melakukan uji praktisi, uji ahli, dan uji desain produk di lapangan. Hasil uji praktisi, uji ahli, dan uji desain produk di lapangandimanfaatkan melakukan revisi akhir terhadap produk pengembangan.R kedua pada RDR adalah kegiatan uji efektivitas produk pengembangan setelah selesai dilakukan proses pengembangan dan revisi akhir. Uji efektivitas produk dilakukan untuk mengetahui layak atau tidaknya produk pengembangan bila digunakan selanjutnya pada proses pembelajaran 
Sehubungan denganitu, data pengembangan dipilah menjadi dua, yakni data kualitatif dan data kuantitatif. Data kualitatif berupa data deskriptif dan data reflektif. Data deskriptif berupa komentar, kritik, saran, koreksi, dan penilaian yang diberikan oleh praktisi dan ahli terhadap desain produk. Selain itu, data deskriptif juga berupa ujaran (lisan dan tulis) dari dosen, mahasiswa, perilaku dosen dan mahasiswa, dan sikap dosen dan mahasiswa dalam proses pembelajaran. Data reflektif berupa komentar dan interpretasi atau tafsiran atas data deskriptif tersebut oleh peneliti. Di sisi lain, data kuantitatif adalah skor tes awal dan tes akhir kemampuan menulis karya ilmiah dalam bentuk makalah mahasiswa yang diperoleh dari pelaksanaan uji efektivitas produk.

Sumber datanya adalah praktisi, ahli, mahasiswa, dosen, dan proses pembelajaran menulis karya ilmiah. Data dari praktisi dan ahli berupa komentar, kritik, saran, koreksi, dan penilaian terhadap desain model pembelajaran menulis karya ilmiah. Data dari mahasiswa berupa ujaran (lisan dan tulis), perilaku, sikap mahasiswa dalam proses pembelajaran, dan skor karya ilmiah mahasiswa sebelum dan sesudah proses pembelajaran. Data dari dosen berupa ujaran (lisan dan tulis), perilaku, sikap dalam proses pembelajaran, komentar, kritik, saran, koreksi, dan penilaian terhadap desain model pembelajaran menulis karya ilmiah. Di sisi lain, data dari proses pembelajaran menulis karya ilmiah berupa pola interaksi mahasiswa-mahasiswa, mahasiswa-dosen, mahasiswa-materi, partisipasi mahasiswa dalam proses pembelajaran, refleksi, dan skor hasil uji efektivitas produk pengembangan.

Kegiatan analisis data pengembangan dipilah menjadi tiga: yakni (a) analisis data dari praktisi dan ahli, (b) analisis data saat uji coba produk, dan (c) analisis data hasil uji efektivitas produk. Kegiatan analisis data dari paraktisi dan ahli dilakukan de- ngan menggunakan teknik analisis domain. Data dikelompokkan berdasarkan domain isi, format, dan bahasa berdasarkan model pembelajaran yang dikembangkan. Setiap domain data dilakukan refleksi untuk dibuat simpulan hasil analisis. Simpulan hasil analisis tersebut dimanfaatkan untuk melakukan revisi terhadap model pembelajaran menulis karya ilmiah.

Kegiatan analisis data dari kegiatan uji efektivitas produk dilakukan dengan analisis statistik. Uji perbedaan skor pretest dan skor postest dari proses pembelajaran dengan menggunakan produk pengembangan dilakukan dengan uji t sampel berpasangan/berhubungan. Kegiatan analisis data statistik hasil kegiatan uji efektivitas produk dilakukan dengan menggunakan SPSS 18.0 for Windows (Santoso, 2005). Alasannya, perangkat analisis statistik tersebut merupakan versi terbaru pada saat kegiatan analisis data ini dilaksanakan. SPSS versi 18.0 memiliki ketajaman analisis yang tinggi dan kelengkapan analisis yang memadai sehingga hasilnya lebih akurat, lebih lengkap, dan memudahkan peneliti dalam menginterpretasikan hasilnya.

\section{HASIL DAN PEMBAHASAN}

Bagian hasil penelitian dan pembahasan ini berisi paparan: (1) proses pengembangan, (2) produk pengembangan, dan (3) pembahasan hasil pengembangan model pembelajaran keterampilan menulis karya ilmiah berpendekatan konstruktivisme untuk meningkatkan keterampilan menulis karya ilmiah mahasiswa. Berikut dipaparkan secara berturut-turut ketiga hal tersebut.

\section{Proses Pengembangan Model Pembe- lajaran}

Proses pengembangan model pembelajaran dilakukan dengan cara berkolaborasi dengan dosen pembina matakuliah Menulis Karya Ilmiah. Kolaborasi de- 
ngan dosen dilakukan untuk mendesain dan mengembangkan model pembelajaran. Melalui kolaborasi diperoleh sejumlah kesepakatan tentang format model pembelajaran yang dikembangkan, penyusunan model pembelajaran, uji praktisi dan uji ahli, uji coba produk di lapangan, dan uji efektivitas produk. Penyusunan model pembelajaranyang dilakukan secara berkolaborasi dengan dosen dimaksudkan untuk memperoleh kesamaan persepsi tentang format model pembelajaranyang dikembangkan.

Berdasarkan hasil kolaborasi dengan dosen berhasil dikembangkan seperangkat model pembelajaran keterampilan menulis karya ilmiah berpendekatan konstruktivisme. Karakteristik model pembelajaran yang dikembangkan sebagai berikut. Model pembelajaran terdiri atas enam komponen penting, yakni (a) pengantar, (b) konsep pembelajaran konstruktivisme, (c) keunggulan pembelajaran dengan pendekatan konstruktivisme, (d) tujuan pembelajaran dengan pendekatan konstruktivisme, (e) karakteristik pembelajaran dengan pendekatan konstruktivisme, dan (f) pelaksanaan pembelajaran dengan pendekatan konstruktivisme. Pelaksanaan pembelajaran terdiri atas tahap (a) persiapan, (b) penjelasan umum, (c) penjelasan teknis, dan (d) tahap penyampaian materi.

Pengantar berisi hal-hal pentingnya perangkat pembelajaran yang dikembangkan dalam penelitian dan landasan yang dimanfaatkan untuk mengembangkan model pembelajaran ini. Pengantar juga berisi maksud dilaksanakannya pengembangan model pembelajaran. Pengantar dikembangkan berdasarkan kolaborasi dengan dosen dan hasil pemikiran bersama dengan dosen.

Konsep pembelajaran konstruktivisme dikembangkan berdasarkan hasil pemikiran bersama dosen. Konsep pembelajaran konstruktivisme berisi cara pembelajar menguasai pengetahuan dan keterampilan yang dipelajari, hal-hal yang mempengaruhi pembelajar, dan peran dosen dalam pembelajaran dengan pendekatan konstruktivisme.

Keunggulan pembelajaran dengan pendekatan konstruktivisme dikembangkan berdasarkan hasil pemikiran bersama dosen. Bagian ini mengungkap sejumlah keunggulan yang dimiliki oleh pendekatan konstruktivisme bila dibandingkan dengan pendekatan konvensional. Tujuan pembelajaran dengan pendekatan konstruktivisme, karakteristik pembelajaran dengan pendekatan konstruktivisme, dan pelaksanaan pembelajaran menulis karya ilmiah dengan pendekatan konstruktivisme juga dikembangkan berdasarkan kolaborasi dan pemikiran bersama dengan dosen.

Pelaksanaan pembelajaran menulis karya ilmiah dengan pendekatan konstruktivisme juga dikembangkan dengan mempertimbangkan kemudahan implementasinya dalam proses pembelajaran. Pembelajaran dengan pendekatan konstruktivisme dirancang untuk memudahkan mahasiswa dalam belajar. Kemudahan itu dapat dicapai bila mahasiswa diberikan kebebasan belajar secara mandiri sesuai dengan gaya belajarnya masing-masing. Akan tetapi, kebebasan itu tetap dalam bimbingan dan pengawan dosen.

Model pembelajaran yang telah didesain selanjutnya dilakukan uji praktisi dan uji ahli. Uji praktisi dan uji ahli yang relevan dilakukan untuk menelaah model pembelajaran yang dikembangkan. Proses uji praktisi dan uji ahli dimaksudkan untuk memperoleh model pembelajaranyang layak dan mantap. Kolaborasi dengan praktisi dan ahli dilakukan untuk memperoleh masukan sebanyak mungkin dari praktisi dan ahli. Praktisi yang ditunjuk untuk melakukan uji adalah dosen pembina matakuliah Menulis Karya Ilmiah. Mereka adalah orang-orang yang memiliki kompetensi dan keterampilan dalam 
pembelajaran menulis karya ilmiah. Perlu diketahui bahwa materi yang diajarkan pada matakuliah Menulis Karya Ilmiah adalah konsep-konsep karya ilmiah dan praktik penyusunan karya ilmiah.

Tim ahli yang ditunjuk untuk melakukan validasi adalah ahli materi/isi pembelajaran menulis karya ilmiah (AMat), ahli metode pembelajaran menulis karya ilmiah (AMet), dan ahli teknologi pembelajaran (ATP). Hasil penelaahan oleh praktisi dan ahli berupa komentar, kritik, saran, perbaikan, dan penilaian yang dituangkan dalam pedoman penilaian atau dituangkan secara langsung dalam format silabus. Kegiatan uji oleh praktisi dan ahli dimaksudkan untuk memantapkan komponen-komponen model pembelajaransecara keseluruhan.

Praktisi dan ahli juga diberikan kewenangan untuk memberikan komentar, kriktik, saran, perbaikan, dan penilaian pada aspek-aspek lain di luar enam komponen utama model pembelajaran. Aspekaspek lain tersebut adalah jenis huruf, ukuran huruf, konsistensi penggunaan istilah, tampilan fisik, tampilan grafis, dan lay out. Paparan hasil uji praktisi dan uji ahli berikut dikelompokkan berdasarkan urutan enam komponen dalam model pembelajaran yang dikembangkan.

\section{Pengantar}

Komponen pengantar model pembelajaran yang diuji oleh praktisi dan ahli adalah (a) pendekatan konstruktivisme dalam pembelajaran menuis karya ilmiah, (b) pentingnya pembelajaran menulis karya ilmiah dengan pendekatan konstruktivisme untuk meningkatkan keterampilan menulis karya ilmiah mahasiswa, kualitas proses, dan kualitas hasil pembelajaran, (c) peran dosen dalam pembelajaran dengan pendekatan konstrukivisme, dan (d) perlunya pendekatan konstruktivis- me dalam pembelajaran di perguruan tinggi. Dari uji praktisi dan uji ahli dapat dinyatakan bahwa komponen pengantar model pembelajaran sudah benar dan sudah sesuai dengan maksud dan tujuan pengembangan model pembelajaran. Hasil uji praktisi dan uji ahli terhadap komponen pengantar model pembelajaran dapat dilihat pada Tabel 1.

Tabel 1. Hasil Uji Komponen Pengantar

\begin{tabular}{cll}
\hline No. & Sumber Data & \multicolumn{1}{c}{ Hasil Uji } \\
\hline 1. & Praktisi 1 & $\begin{array}{l}\text { Pengantar sudah } \\
\text { benar }\end{array}$ \\
2. & Praktisi 2 & Sudah benar \\
3. & Praktisi 3 & Sudah sesuai \\
4. & AMat & Sudah ok \\
5. & AMet & Sudah ok \\
6. & ATp & Sudah benar \\
\hline
\end{tabular}

\section{Konsep Pembelajaran Konstruktivisme}

Komponen konsep pembelajaran konstruktivisme dalam model pembelajaran yang diuji oleh praktisi dan ahli adalah bagaimana pengetahuan disusun dalam diri mahasiswa. Berdasarkan paham konstruktivisme, dalam proses pembelajaran dosen tidak serta merta memindahkan pengetahuan kepada mahasiswa dalam bentuk yang sempurna. Mahasiswa harus membangun pengetahuan berdasarkan pengalaman mereka masing-masing. Peran dosen dalam pembelajaran hanyalah sebagai fasilitator, pembimbing belajar, tempat bertanya mahasiswa, narasumber, dan motivator belajar mahasiswa. Dari hasil uji praktisi dan uji ahli dapat dinyatakan bahwa komponen konsep pembelajaran konstruktivisme sudah benar dan layak diterapkan dalam proses pembelajaran menulis karya ilmiah. Hasil uji praktisi dan uji ahli terhadap komponen konsep pembelajaran konstruktivisme dalam model pembelajarandapat dilihat pada Tabel 2. 
Tabel 2. Hasil Uji Komponen Konsep Pembelajaran Konstruktivisme

\begin{tabular}{cll}
\hline No. & Sumber Data & \multicolumn{1}{c}{ Hasil Uji } \\
\hline 1. & Praktisi 1 & Sudah benar \\
2. & Praktisi 2 & Sudah benar \\
3. & Praktisi 3 & Sudah sesuai \\
4. & AMat & Sudah ok \\
5. & AMet & Sudah benar \\
6. & ATp & Sudah ok \\
\hline
\end{tabular}

Keunggulan Pembelajaran dengan Pendekatan Konstruktivisme

Komponen keunggulan pembelajaran dengan pendekatan konstruktivisme dalam model pembelajaranyang diuji oleh praktisi dan ahli adalah: (a) pendekatan kostruktivisme memiliki sejumlah keunggulan dibandingkan dengan pendekatan behaviorisme/konvensional dalam pembelajaran (menulis karya ilmiah), (b) dalam pembelajaran dengan pendekatan konstruktivisme mahasiswa dipandang sebagai fokus pembelajaran, dan (c) dalam membangun pengetahuan dan keterampilan mahasiswa harus mandiri dan aktif melalui sejumlah interaksi yang bermakna dengan lingkungan sosial budayanya (Johnson, 2002). Dari hasil uji praktisi dan uji ahli dapat dinyatakan bahwa komponen keunggulan pembelajaran dengan pendekatan konstruktivisme perlu dielaborasi lagi. Meskipun saran hanya berasal dari satu orang praktisi, saran tersebut tetap harus diperhatikan dan dilakukan. Revisi terhadap komponen keunggulan pembelajaran dengan pendekatan konstruktivisme dalam model pembelajaran dituangkan secara langsung pada model pembelajaran produk pengembangan. Hasil uji praktisi dan uji ahli terhadap komponen keunggulan pembelajaran dengan pendekatan konstruktivisme dalam panduan pelaksanaan proses pembelajaran dapat dilihat pada Tabel 3.
Tabel 3. Hasil Uji Komponen Keunggulan PembelajaranKonstruktivisme

\begin{tabular}{cll}
\hline No. & Sumber Data & \multicolumn{1}{c}{ Hasil Uji } \\
\hline 1. & Praktisi 1 & Perlu dielaborasi \\
& & lagi \\
2. & Praktisi 2 & Sudah ok \\
3. & Praktisi 3 & Sudah sesuai \\
4. & AMat & Sudah sesuai \\
5. & AMet & Sudah ok \\
6. & ATp & Sudah ok \\
\hline
\end{tabular}

Tujuan Pembelajaran MKI dengan Pendekatan Konstruktivisme

Komponen tujuan pembelajaran MKI dengan pendekatan konstruktivisme dalam model pembelajaran yang diuji oleh praktisi dan ahli adalah: (a) pembelajaran menulis karya ilmiahberpendekatan konstruktivisme dimaksudkan untuk meningkatkan peran aktif mahasiswa secara intelektual dan emosional dalam proses pembelajaran, (b) pembelajaran menulis karya ilmiah berpendekatan konstruktivisme dimaksudkan untuk meningkatkan keterampilan menulis karya ilmiah mahasiswa, kualitas proses, dan kualitas hasil pembelajaran, (c) mahasiswa didorong untuk menemukan atau membangun sendiri konsep yang dipelajari melalui penafsiran yang dilakukan dengan berbagai cara, seperti observasi, diskusi, percobaan, atau yang lain, dan (d) pembelajaran dengan pendekatan konstruktivisme dimaksudkan untuk memberikan kesempatan kepada mahasiswa bertanggung jawab menyelesaikan tugas bersama. Dari hasil uji praktisi dan uji ahli dapat dinyatakan bahwa komponen tujuan pembelajaran menulis karya ilmiah dengan pendekatan konstruktivisme dalam model pembelajaran sudah sesuai dengan kebutuhan pembelajaran. Hasil uji praktisi dan uji ahli terhadap komponen tujuan pembelajaran MKI dengan pendekatan konstruktivisme dalam model pembelajaran dapat dilihat pada Tabel 4 . 
Tabel 4. Hasil Uji Komponen Tujuan Pembelajaran Konstruktivisme

\begin{tabular}{cll}
\hline No. & Sumber Data & \multicolumn{1}{c}{ Hasil Uji } \\
\hline 1. & Praktisi 1 & Sudah sesuai \\
2. & Praktisi 2 & Sudah ok \\
3. & Praktisi 3 & Sudah sesuai \\
4. & AMat & Sudah sesuai \\
5. & AMet & Sudah ok \\
6. & ATp & Sudah ok \\
\hline
\end{tabular}

\section{Karakteristik Pembelajaran Berpendekat-} an Konstruktivisme

Komponen karakteristik pembelajaran dengan pendekatan konstruktivisme dalam model pembelajaranyang diuji oleh praktisi dan ahli adalah: (a) pembelajaran ditekankan pada perubahan perilaku mahasiswa setelah memperoleh pembelajaran, (b) partisipasi aktif mahasiswa dalam pembelajaran menjadi penekanan utama, dan (c) pengetahuan diperoleh mahasiswa melalui proses interaksi yang bermakna dengan lingkungan sosial budaya sekitarnya. Dari hasil uji ahli dan praktisi dapat dinyatakan bahwa komponen karakteristik pembelajaran dengan pendekatan konstruktivisme dalam model pembelajaran sudah benar/layak. Hasil uji praktisi dan uji ahli terhadap komponen karakteristik pembelajaran dengan pendekatan konstruktivisme dalam model pembelajaran dapat dilihat pada Tabel 5 .

Tabel 5. Hasil Uji Komponen KarakteristikPembelajaran Konstruktivisme

\begin{tabular}{cll}
\hline No. & Sumber Data & \multicolumn{1}{c}{ Hasil Uji } \\
\hline 1. & Praktisi 1 & Sudah sesuai \\
2. & Praktisi 2 & Sudah ok \\
3. & Praktisi 3 & Sudah benar \\
4. & AMat & Sudah benar \\
5. & AMet & Sudah ok \\
6. & ATp & Sudah ok \\
\hline
\end{tabular}

\section{Pelaksanaan Pembelajaran MKI Ber- pendekatan Konstruktivisme}

Komponen pelaksanaan pembelajaran menulis karya ilmiah dengan pendekatan konstruktivisme dalam model pembelajaran menulis karya ilmiah yang diuji oleh praktisi dan ahli adalah: (a) kegiatan pendahuluan, (b) kegiatan inti, dan (c) kegiatan penutup. Pertama, kegiatan pendahuluan diisi kegiatan orientasi, yakni membuka perkuliahan dengan aktivitas menyampaikan tujuan pembelajaran, KD, sistem evaluasi yang akan digunakan, dan apersepsi. Kedua, kegiatan inti berupa kegiatan eksplorasi konsep, kegiatan interpretasi/penemuan konsep, kegiatan aplikasi konsep, dan evaluasi. Terakhir, ketiga, kegiatan penutup diisi dengan aktivitas refleksi, penyimpulan, dan evaluasi formatif.

Dari hasil uji praktisi dan uji ahli dapat dinyatakan bahwa komponen pelaksanaan pembelajaran menulis karya ilmiah dengan pendekatan konstruktivisme dalam model pembelajaran perlu disusun kembali agar lebih praktis. Petunjuk pelaksanaan proses pembelajaran sebaiknya menggunakan kalimat-kalimat yang simpel. Revisi terhadap komponen pelaksanaan pembelajaran menulis karya ilmiah dengan pendekatan konstruktivisme dalam model pembelajaran menulis karya ilmiah selengkapnya dituangkan dalam model pembelajaran menulis karya ilmiah produk pengembangan. Hasil uji praktisi dan uji ahli terhadap komponen pelaksanaan pembelajaran menulis karya ilmiah dengan pendekatan konstruktivisme dalam model pembelajaran menulis karya ilmiah dapat dilihat pada Tabel 6 .

Berdasarkan hasil uji praktisi dan uji ahli tersebut dilakukan revisi terhadap komponen-komponen model pembelajaranmenulis karya ilmiah berpendekatan konstruktivisme. Revisi dilakukan berdasarkan sejumlah kritik, komentar, saran, perbaikan, dan penilaian yang diberikan oleh praktisi dan ahli. Revisi juga dilaku-

Pengembangan Model Pembelajaran Menulis Karya Ilmiah Berpendekatan Konstruktivisme 
kan terhadap kesalahan pengetikan, jenis huruf, ukuran huruf, konsistensi penggunaan kata dan istilah, tampilan fisik, tampilan grafis, dan lay outsilabus.

Tabel 6. Hasil Uji Komponen Pelaksanaan Pembelajaran Konstruktivisme

\begin{tabular}{|c|c|c|}
\hline No. & Sumber Data & Hasil Uji \\
\hline 1. & Praktisi 1 & $\begin{array}{l}\text { Petunjuk pelaksanaan } \\
\text { pembelajaran kurang } \\
\text { praktis }\end{array}$ \\
\hline 2. & Praktisi 2 & $\begin{array}{l}\text { Perlu dipraktiskan lagi } \\
\text { petunjuknya }\end{array}$ \\
\hline 3. & Praktisi 3 & $\begin{array}{l}\text { Perlu direvisi agar lebih } \\
\text { praktis }\end{array}$ \\
\hline 4. & AMat & Perlu kepraktisan \\
\hline 5. & AMet & Perlu direvisi agar praktis \\
\hline 6. & ATp & Perlu dipraktiskan lagi. \\
\hline
\end{tabular}

Langkah pengembangan berikutnya adalah uji coba model pembelajaran di lapangan. Uji coba model pembelajaran dilakukan dalam dua tahap, yakni uji coba pada kelompok kecil dan uji coba pada kelompok besar. Uji coba model pembelajaran dilakukan melalui kolaborasi dengan dosen dan mahasiswa dengan cara mengimplementasikan model pembelajaran dalam proses pembelajaran. Uji coba model pembelajaran dilakukan untuk memperoleh masukan sebanyak mungkin dari dosen dan mahasiswa untuk keperluan penyempurnaan model pembelajaran.

Secara garis besar hasil pelaksanaan uji coba model pembelajaran dipaparkan sebagai berikut. Pertama, secara umum model pembelajaran produk pengembangan dapat diujicobakan dengan baik. Model pembelajaran dapat diiplementasikan dengan baik dalam proses pembelajaran menulis karya ilmiah. Hal itu dimungkinkan karena dosen juga diikutsertakan dalam mendesain model pembelajaran.

Kedua, terdapat sejumlah kelemahan yang ditemukan dalam model pembelajaran. Kelamahan tersebut adalah adanya kesalahan ketik, kesalahan pilihan kata dan istilah, dan kalimat tidak terlalu jelas dalam model pembelajaran. Ketidakjelasan kalimat umumnya terdapat pada komponen pelaksanaan pembelajaran sehingga kadang-kadang membingungkan dosen dalam melaksanakan proses pembelajaran.

Ketiga, terdapat hal-hal yang perlu diperhatikan oleh dosen dalam pembelajaran menulis karya ilmiah dengan pendekatan konstruktivisme. Dosen perlu mempersiapkan mental mehasiswa dengan baik. Mahasiswa harus diberitahu sejak awal bahwa partisipasi aktif dalam proses pembelajaran adalah menjadi tuntutan utama. Mahasiswa dituntut membangun pengetahuan dan keterampilan sejak awal dalam rangkaian menulis karya ilmiah. Mahasiswa juga dituntut aktif berinteraksi dengan dosen, materi, teman sejawat, dan strategi untuk membangun pengetahuan dan keterampilan menulis karya ilmiah.

Keempat, diperlukan waktu yang relatif banyak dalam pelaksanaan pembelajaran dengan pendekatan konstruktivisme. Hal itu disebabkan karena pembelajaran dengan pendekatan konstruktivisme membutuhkan serangkaian proses yang panjang untuk sampai pada suatu kesepakatan akhir.

Revisi model pembelajaran dilakukan setiap kali selesai uji coba model pembelajaran pada setiap kali pertemuan. Revisi model pembelajaran dilakukan dengan cara melakukan refleksi dan diskusi bersama dengan dosen dan mahasiswa. Berdasarkan hasil uji coba, revisi dilakukan terhadap kesalahan pengetikan, kesalahan penggunaan kata dan istilah dan kalimat yang kurang jelasdalam model pembelajaran. Revisi juga dilakukan terhadap kesalahan dan kekurangkomunikatifan kalimat, kekurangsempurnaan lay out, dan aspek kebahasaan lainnya dalam model pembelajaran. Hasil revisi/penyempurnaan tersebut dituangkan langsung da-lam model pembelajaran revisi. 
Hasil penyempurnaan berupa seperangkat model pembelajaran menulis karya ilmiah berpendekatan konstruktivisme yang layak dan mantap, serta siap diimplementasikan dalam uji efektivitas produk pengembangan di lapangan.

\section{Produk Pengembangan Model Pem- belajaran Keterampilan MenulisKarya Ilmiah}

Produk akhir dari pelaksanaan proses pengembangan adalah seperangkat model pembelajaran menulis karya ilmiah berpendekatan konstruktivisme. Produk pengembangan tersebut telah siap diimplementasikan dalam proses pembelajaran oleh semua pihak yang berkepentingan dengan peningkatan keterampilan menulis karya ilmiah mahasiswa, kualitas proses, dan kualitas hasil pembelajaran. Berikut dipaparkan secara ringkas produk akhir dari proses pengembangan model pembelajaran keterampilan menulis karya ilmiah.

Model pembelajaran keterampilan menulis karya ilmiah berpendekatan konstruktivisme dikembangkan berdasarkan hasil kolaborasi dengan dosen pembina, hasil pemikiran bersama dosen pembina, contoh-contoh model pembelajaran menulis karya ilmiah, kemudahan implementasinya dalam proses pembelajaran, dan pertimbangan kebutuhan belajar mahasiswa. Hal itu dimaksudkan agar model pembelajaran keterampilan menulis karya ilmiah hasil pengembangan dapat diimplementasikan dalam proses pembelajaran.

Model pembelajaran keterampilan menulis karya ilmiah berpendekatan konstruktivisme hasil pengembangan ini terdiri atas enam komponen penting, yakni: (a) pengantar, (b) konsep pembelajaran konstruktivisme, (c) keunggulan pembelajaran dengan pendekatan konstruktivisme, (d) tujuan pembelajaran keterampilan menulis karya ilmiah dengan pendekatan konstruktivisme, (e) karak- teristik pembelajaran dengan pendekatan konstruktivisme, dan (f) pelaksanaan pembelajaran keterampilan menulis karya ilmiah berpendekatan konstruktivisme yang terdiri atas: (i) persiapan, (ii) penjelasan umum, (iii) penjelasan teknis, dan (iv) pelaksanaan pembelajaran. Model pembelajaran selengkapnya dapat dilihat pada produk pengembangan yang dijilid terpisah dengan naskah laporan penelitian. Penjelasan ringkas setiap komponen panduan pelaksanaan proses pembelajaran sebagai berikut.

Pertama, pengantar berisi penjelasan tentang latar belakang pentingnya disusun model pembelajaran menulis karya ilmiah. Dalam latar belakang diungkap (a) pentingnya pemanfaatan perangkat pembelajaran hasil pengembangan untuk meningkatkan keterampilan menulis karya ilmiah mahasiswa, kualitas proses, dan kualitas hasil pembelaran, (b) peran dosen dalam pembelajaran dengan pendekatan konstrukivisme, (c) pendekatan konstruktivisme dalam pembelajaran menuis karya ilmiah, dan (d) perlunya pendekatan konstruktivisme dalam pembelajaran di perguruan tinggi.

Kedua, konsep pembelajaran konstruktivisme berisi penjelasan bagaimana pengetahuan disusun dalam diri mahasiswa. Berdasarkan paham konstruktivisme, dalam proses pembelajaran dosen tidak serta merta memindahkan pengetahuan kepada mahasiswa dalam bentuk yang sempurna. Mahasiswa harus membangun pengetahuan dan keterampilan berdasarkan pengalaman mereka masingmasing. Peran dosen dalam pembelajaran hanyalah sebagai fasilitator, pembimbing belajar, tempat bertanya mahasiswa, narasumber, dan motivator belajar mahasiswa.

Ketiga, keunggulan pembelajaran berpendekatan konstruktivisme dibandingkan dengan pendekatan behaviorisme/ konvensional dalam pembelajaran (menulis karya ilmiah). Dalam pembelajaran

Pengembangan Model Pembelajaran Menulis Karya Ilmiah Berpendekatan Konstruktivisme 
dengan pendekatan konstruktivisme, mahasiswa dipandang sebagai fokus pembelajaran. Bahwa mahasiswa sebagai fokus pembelajaran tampak pada partisipasi aktif mahasiswa dalam membangun pengetahuan dan keterampilan yang dipelajarinya melaui sejumlah interaksi yang bermakna dengan lingkungan sosial budayanya. Dalam hal itu, ditekankan bahwa mahasiswa harus mandiri dan aktif dalam membangun pengetahuan dan keterampilan melalui sejumlah interaksi yang bermakna dengan lingkungan social budayanya. Lingkungan sosial mahasiswa tersebut meliputi teman sejawat, dosen, materi, strategi belajar, ahli yang relevan, dan bahkan dengan orang lain.

Keempat, tujuan pembelajaran keterampilan menulis karya ilmiah berpendekatan konstruktivisme yakni untuk meningkatkan peran aktif mahasiswa secara intelektual dan emosional dalam proses pembelajaran. Pembelajaran menulis karya ilmiah berpendekatan konstruktivisme juga dimaksudkan untuk meningkatkan keterampilan menulis karya ilmiah mahasiswa, kualitas proses, dan kualitas hasil pembelajaran. Mahasiswa didorong untuk menemukan atau membangun sendiri konsep yang dipelajari melalui penafsiran yang dilakukan dengan berbagai cara, seperti observasi, diskusi, percobaan, atau yang lain. Pembelajaran dengan pendekatan konstruktivisme juga dimaksudkan untuk memberikan kesempatan kepada mahasiswa bertanggung jawab menyelesaikan tugas bersama.

Kelima, krakteristik pembelajaran berpendekatan konstruktivismeyang berbeda dengan pembelajaran yang memanfaatkan pendekatan jenis lain (pendekatan behaviorisme/konvensional). Sejumlah karakteristik pembelajaran dengan pendekatan konstruktivisme adalah: (a) pembelajaran ditekankan pada perubahan perilaku mahasiswa setelah memperoleh pembelajaran, (b) partisipasi aktif mahasiswa dalam pembelajaran menjadi penekanan utama, dan (c) pengetahuan diperoleh mahasiswa melalui proses interaksi yang bermakna.

Keenam, pelaksanaan pembelajaran keterampilan menulis karya ilmiah berpendekatan konstruktivisme dibagi dalam tiga kelompok kegiatan, yakni: (a) kegiatan pendahuluan, (b) kegiatan inti, dan (c) kegiatan penutup. Pertama, kegiatan pendahuluan diisi kegiatan orientasi, yakni membuka perkuliahan dengan aktivitas menyampaikan tujuan pembelajaran, KD, sistem evaluasi yang akan digunakan, dan apersepsi. Kedua, kegiatan inti berupa kegiatan eksplorasi konsep, kegiatan interpretasi/penemuan konsep, dan kegiatan aplikasi konsep. Terakhir, ketiga, kegiatan penutup diisi dengan aktivitas refleksi, penyimpulan, dan evaluasi formatif.

\section{Uji Efektivitas Produk Pengembangan}

Uji efektivitas produk pengembangan dimaksudkan untuk memperoleh informasi tentang efektif atau tidakya produk pengembangan ini bila diimplementasikan dalam proses pembelajaran menulis karya ilmiah berpendekatan konstruktivisme di lapangan. Uji efektivitas dilakukan dengan cara melakukan uji beda prestasi belajar mahasiswa sebelum dan sesudah proses pembelajaran dengan menggunakan produk pengembangan. Prestasi belajar menulis karya ilmiah mahasiswa tersebut diwujudkan dalam bentuk skor. Desain yang digunakan adalah desain pretes dan postes kelompok tunggal.

Dari hasil uji statistik diperoleh informasi bahwa terdapat perbedaan antara skor pretes dan skor postes pada proses pembelajaran menulis karya ilmiah yang memanfaatkan produk pengembangan. Skor rata-rata pretes penyusunan makalah adalah 74,96 dan skor rata-rata postes adalah 89,04. Perbedaan skor dari pemanfaatan produk pengembangan adalah 14,08 . Hasil uji $t$ sampel berhubungan menunjukkan signifikansi ( 2 ekor) $\mathrm{p}=0,000$ $<\alpha=0,005$. 
Hal itu berarti bahwa terdapat perbedaan yang signifikan antara skor pretes dan skor postes. Dari hasil penghitungan tersebut tampak bahwa pemanfaatan produk pengembangan dalam proses pembelajaran menulis karya ilmiah memiliki pengaruh positif secara signifikan terhadap prestasi belajar menulis karya ilmiah mahasiswa. Berdasarkan hasil penghitungan itu dapat dinyatakan bahwa terjadi peningkatan prestasi belajar menulis karya ilmiah mahasiswa secara nyata antara sebelum proses pembelajaran dan sesudah proses pembelajaran.

Di samping itu, peningkatan juga terjadi pada keterampilan menulis karya ilmiah mahasiswa dan kualitas proses pembelajaran. Peningkatan keterampilan menulis karya ilmiah mahasiswa tampak pada meningkatnya prestasi pembelajaran menulis karya ilmiah mahasiswa. Peningkatan kualitas proses pembelajaran menulis karya ilmiah tampak pada meningkatnya minat, motivasi, partisipasi mahasiswa secara fisik dan kejiwaan, interaksi dengan teman sejawat, dosen, ahli yang relevan dengan bidang kajian, sikap mau memberi dan menerima pendapat orang lain, keterbukaan, tanggung jawab, kepekaan sosial, dan sikap demokratis dalam belajar.

Dari kegiatan uji efektivitas telah terbukti bahwa model pembelajaran produk pengembangan ini dapat meningkatkan keterampilan menulis karya ilmiah mahasiswa, kualitas proses, dan kualitas hasil pembelajaran. Peningkatan keterampilan menulis karya ilmiah mahasiswa dapat diamati dari meningkatnya kualitas karya ilmiah dalam bentuk makalah sebelum dan sesudah proses pembelajaran dengan pendekatan konstruktivisme. Peningkatan kualitas proses pembelajaran dapat diamati dari meningkatnya interaksi yang terjadi dalam proses pembelajaran. Interaksi tersebut terjadi secara timbal balik antara dosen-mahasiswa-materi pembelajaran-media, dan strategi pembelajara.
Interaksi yang terjadi menuntutpartisipasi aktif mahasiswa, baik secara fisik maupun kejiwaan (intelegensi, bakat, minat, motivasi, kesadaran, dan emosi) dalam proses pembelajaran. Peningkatan kualitas hasil pembelajaran dapat dilihat dari adanya perpebedaan skor pretes dan postes hasil karya ilmiah mahasiswa dalam bentuk makalah.

Dari kegiatan uji coba model pembelajaran diperoleh data bahwa terdapat peningkatan nyata keterampilan menulis karya ilmiah dan partisipasi mahasiswa dalam proses pembelajaran. Mahasiswa telah termotivasi, antusias, bersemangat, aktif secara fisik dan kejiwaan dalam mengikuti seluruh rangkaian proses pembelajaran menulis karya ilmiah selama satu semester. Peningkatan keterampilan menulis karya ilmiah tersebut penting bagi mahasiswa untuk menunjang kelancaran dan kesuksesan studinya di perguruan tinggi. Keterampilan menulis karya ilmiah mutlak bagi mahasiswa, karena setiap hari mahasiswa berkutat dengan tugas-tugas ilmiah.

Model pembelajaran produk pengembangan ini dimanfaatkan untuk memenuhi kebutuhan pembelajaran menulis karya ilmiah dengan pendekatan konstruktivisme. Mengingat model pembelajaran yang ada selama ini berpendekatan behaviorisme, produk pengembangan ini dapat dimanfaatkan untuk memenuhi kebutuhan pembelajaran menulis karya ilmiah dengan pendekatan konstruktivisme tersebut. Model pembelajaran produk pengembangan ini dapat dimanfaatkan sebagai pedoman pelaksanaan proses pembelajaran, interaksi proses pembelajaran, dan pelaksanaan proses evaluasi, baik evaluasi proses maupun evaluasi hasil pembelajaran menulis karya ilmiah dengan pendekatan konstruktivisme. Dengan pemanfaatan model pembelajaran berpendekatan konstruktivisme yang layak dan mantap diharapkan keterampilan menulis karya ilmiah maha-

Pengembangan Model Pembelajaran Menulis Karya Ilmiah Berpendekatan Konstruktivisme 
siswa, kualitas proses, dan kualitas hasil pembelajaran dapat meningkat secara optimal. Pemanfaatan model pembelajaran produk pengembanganini dalam proses pembelajaran (kegiatan uji efektivitas) telah terbukti dapat meningkatkan keterampilan menulis karya ilmiah mahasiswa, kualitas proses, dan kualitas hasil/prestasi pembelajaran.

\section{SIMPULAN}

Berdasarkan hasil penelitian pengembangan ini, yakni pengembangan model pembelajaran menulis karya ilmiah berpendekatan konstruktivisme dapat disimpulkan sebagai berikut. Dalam implementasinya model pembelajaran tersebut terbukti dapat meningkatkan keterampilan menulis karya ilmiah mahasiswa. Peningkatan keterampilan dapat dilihat dari dua aspek, yakni peningkatan partisipasi mahasiswa dan peningkatan prestasi belajar mahasiswa. Peningkatan partisipasi mahasiswa tampak nyata pada partisipasi aktif mahasiswa, baik secara fisik maupun kejiwaan dalam proses pembelajaran.

Di sisi lain, peningkatan prestasi belajar mahasiswa dapat dilihat dari meningkatnya skor hasil akhir belajar mereka, yakni selisih antara skor pretes dan skor postes. Peningkatan prestasi belajar mahasiswa sangat signifikan. Peningkatan prestasi belajar mahasiswa juga dapat dilihat perbandingan antara skor hasil belajar dengan model konstruktivisme dengan memanfaatkan produk pengembangan dan skor belajar dengan model konvensional tanpa memanfaatkan produk pengembangan. Perbandingan di antara keduanya menunjukkan bahwa skor hasil belajar dengan model pembelajaran konstruktivisme lebih tinggi daripada skor hasil belajar dengan model pembelajaran konvensional. Hal itu menunjukkan bahwa pembelajaran dengan model konstruktivisme dapat meningkatkan kualitas proses dan hasil belajar mahasiswa secara signifikan.
Hasil kegiatan eksperimen juga membuktikan bahwa proses pembelajaran berpendekatan konstruktivisme telah menunjukkan adanya sejumlah keunggulan dibandingkan dengan pembelajaran dengan model behaviorisme/konvensional. Begitu juga proses pembelajaran berpendekatan konstruktivisme dapat meningkatkan keterampilan menulis karya ilmiah mahasiswa. Di samping itu, proses pembelajaran dengan model konstruktivisme dapat meingkatkan kualitas proses pembelajaran menulis karya ilmiah ke arah pembelajaran yang demokratis (Basuki, 2008:252).

\section{UCAPAN TERIMA KASIH}

Artikel ini disarikan dari Disertasi yang berjudul Pengembangan Perangkat Pembelajaran Keterampilan Menulis Karya Ilmiah Berpendekatan Konstruktivisme pada Program Studi Pendidikan Bahasa Indonesia, Program Pascasarjana Universitas Negeri Malang. Ucapan terima kasih disampaikan kepada para Pembimbing: (I) Prof. Dr. H. Suparno, (II) Prof. Dr. Djoko Saryono, M.Pd, dan (III) Prof. Dr. H. Abdul Syukur Ibrahim.Ucapan terima kasih juga disampaikan kepada sejawat yang telah membantu proses penelitian dan penulisan artikel ini. Harapannya, artikel ini dapat memberi sumbangan dalam mengembangkan kemampuan menulis karya ilmiah, khususnya bagi para mahasiswa.

\section{DAFTAR PUSTAKA}

Basuki, Imam Agus. 2008. "Pengembangan Model Penilaian Sejawat untuk Meningkatkan Hasil Pembelajaran Menulis di SMP". Disertasi tidak diterbitkan. Malang: PPS Universitas Negeri Malang.

Borg, W.R. and M.D. Gall. 1983. Educational Research: An Introduction, 4 th edition. London: Longman Inc.

Johnson, Elaine B. 2002. Contextual Teaching and Learning. Thousand Oaks: Corwin Press, Inc. 
Nur, Muhammad. 1998. Pendekatanpendekatan Konstruktivime dalam Pembelajaran. Surabaya: Program Pascasarjana IKIP Surabaya.

Nurjanah, Nunuy. 2005. "Penerapan Model Konstruktivisme dalam Pembelajaran Menulis Bahasa Indonesia". Disertasi tidak diterbitkan. Bandung: PPS UPI Bandung.

Santoso, S. 2005. SPSS Versi 16.0 Mengolah Data Statistik secara Profesional. Jakarta: PT Elek Media Komputindo.

Shymansky, J. 1992. “Using Constructivist Ideas to Teach Science Teachers about Constructivis Ideas, or Teachers are student Too!". Journal of Science Teacher Education, 3 (2), 53-57.

Suparno, Paul. 1997. Filsafat Konstruktivisme dalam Pendidikan. Yogyakarta: Penerbit Kanisius.
Vygotsky, L.S. 1978. Mind in Society. Cambridge: Harvard University Press.

Vygotsky, L.S. 2002. Characteristics of Constructivist Learning and Teaching. (Online), (http:// www. stemnet.nf.ca), diakses 10 Agustus 2009.

Willis, Jerry. 1995. A Recursive, Reflective Instructional Design Model Based on Constructivist-Interpretivist Theory. Educational Technology, (Online),35 (6), 5-23, diakses 17 Desember 2009.

Willis, Jerry. 2000. The Maturing of Constructivist Instructional Design: Some Basic Principles that Can Guide Practice. Educational Technology, (Online), 40 (1), 5-16, diakses 15 Desember 2009. 